www.czasopisma.marszalek.com.pl/pl/10-15804/npw

\author{
Saltanat KuZEmbayeva \\ University of Warsaw \\ ORCID: https://orcid.org/0000-0003-4060-1890
}

\title{
Participation of Kazakhstan in the Chinese “One Belt, One Road" Initiative: Advantages, Problems and Prospects
}

\section{Participation of Kazakhstan in the Chinese "One Belt, One Road" Initiative: Advantages, Problems and Prospects}

\section{Abstract}

The article is devoted to the geoeconomic goals and prospects of implementing the Chinese initiative „One Belt, One Road”. The author explores the benefits, problems and future opportunities that open up to the Republic of Kazakhstan as a participant in this initiative. The analysis carried out in the article showed that there are still many problems in the implementation of the Silk Road Economic Belt (SREB) project taking into account the state program of Kazakhstan "Nurly Zhol", and difficulties arise in the practical implementation of various cooperation areas. At the same time, Kazakhstan should be guided exclusively by its national interests in cooperation with China in the framework of the "One Belt, One Way" initiative.

Keywords: One Belt, One Road Initiative, China, Kazakhstan, the "Silk Road Economic Belt” (SREB), Program "Nurly Zhol”, The Eurasian Economic Union (EEU), problems, prospects 


\section{Участие Казахстана в китайской инициативе «Один Пояс - Один Путь»: преимущества, проблемы и перспективы}

\section{Аннотация}

Статья посвящена геоэкономическим целям и перспективам реализации китайской инициативы «Один пояс - Один путь». Автор исследует выгоды, проблемы и перспективы, которые открываются перед Республикой Казахстан как участником данной инициативы. Проведенный в статье анализ показал, что на пути реализации проекта «Экономический пояс Шелкового пути» (ЭПШП), с учетом государственной программы Казахстана «Нурлы жол», еще много проблем, сложности возникают и с практической реализацией разных направлений сотрудничества. Вместе с тем Казахстану следует руководствоваться исключительно своими национальными интересами в сотрудничестве с Китаем в рамках инициативы «Один пояс - один путь».

Ключевые слова: Инициатива «Один пояс - один путь», Китай, Казахстан, «Экономический пояс Шелкового пути» (ЭПШП), Программа «Нурлы жол», Евразийский экономический союз (ЕАЭС), проблемы, перспективы

G eoeconomics is new geopolitics based on the economic power of the state, which ensures the achievement of foreign policy goals, regional and world power by economic means (Luttwak, 2012, p. 8). The term "geoeconomics" was introduced in the 1960s into scientific circulation by the American political scientist, economist and military historian E. Luttvak. It seems that the project "One Belt, One Way" proposed by China is a clear example of Beijing's desire to gain world leadership by strengthening its economic power (Marszałek-Kawa, Dmochowski, 2018).

The Chinese project on the creation and development of the global transport and investment infrastructure "One Belt, One Road" includes two initiatives: the "Silk Road Economic Belt" (SREB) and the "Sea Silk Road of the $21^{\text {st }}$ Century" (SSR).

SREB is a project aimed at creating a single Eurasian trade and economic space and a transcontinental transport corridor. This project got its name in honor of the ancient Silk Road (it was a caravan route that connected China with Europe through Central Asia; it operated from the 2nd century BC to the $15^{\text {th }}$ century). 
The idea of the modern project "One Belt, One Way" was voiced in September 2013 by the President of the People's Republic of China Xi Jinping at Nazarbayev University (Astana), and he identified five priority tasks that the SREB should solve:

- Ensuring large-scale regional economic integration;

- Construction of a trans-Asian transport infrastructure;

- Elimination of trade and investment barriers;

- Strengthening national currencies;

- Expansion of humanitarian cooperation.

China believes that 67 countries, whose total population exceeds $63 \%$ of the world, will join the SREB. The project was designed for 30 years (Wong, 2014).

The developers of the project believe that the SREB will reduce the time for delivery of goods from China to Europe. Now days, the average delivery time for containerized cargo by sea is 45-60 days. SREB will reduce this period to 10 days. In addition to the formation of a single transport infrastructure, the project will significantly expand customs cooperation, increase the volume of financial transactions between states, and establish financial institutions under various regional organizations (BRICS, SCO). Strengthening humanitarian ties involves an active exchange in the field of science, culture and media.

At present, a clear route for the New Silk Road has not been developed. According to official data, the project is based on the construction of three railway corridors (northern, central and southern ones). It is planned that they will connect the eastern provinces of China with the states of Western Europe.

It is assumed that the Northern corridor through the Republic of Kazakhstan and the Russian Federation will pass to the Baltic Sea, in the west it will pass through Belarus and Poland and eventually reach Germany and Holland.

The central corridor is the most complicated in terms of the political situation and insufficient infrastructure, it is designed to connect the ports of eastern China (Shanghai, Lianyungang) with the states of Central Asia (Uzbekistan, Kyrgyzstan, Turkmenistan), Iran, Turkey, and then pass through the Balkan Peninsula to France. It will require the construction of a tunnel under the Bosphorus Strait in Istanbul (Turkey). 
In addition to the land transport corridor, China also intends to develop the concept of maritime trade routes, which is called the "Sea Silk Road of the 21st Century" (SSR). Xi Jinping announced the relevant plans in October 2013 in Indonesia. The sea route will begin in Fuzhou, then continue through Guangzhou and Hainan, then pass through the Strait of Malacca and through the Indian Ocean, go around the Horn of Africa and head to the Red and Mediterranean Seas. Another area of the SSR will leave China's ports in the South Pacific.

At the APEC summit in November 2014, China expressed its intention to allocate USD 40 billion to form the Silk Road Fund. It will be used to financially support the construction of infrastructure and ensure financial interaction between the participants of the One Belt, One Way project in different regions of the world. In May 2017, the President Xi Jinping increased the size of the Fund by USD 14.5 billion (Чжоу, 2019, с. 37).

There is another financial mechanism, the Asian Infrastructure Investment Bank (AIIB), which was established at the initiative of the PRC in October 2014. Nowadays, 57 countries of the Asia-Pacific Region (APR), the Middle East, Europe and Latin America take part in it. Russia joined the AIIB in 2015 with a share of USD 6.5 billion in the total capital of the Bank, which is about USD 100 billion (Чжоу, 2019, с. 38).

$\mathrm{Xi}$ Jinping drew attention to the fact that in 2015 Chinese investors invested about USD 15 billion in states participating in the SREB and SSR projects. For example, Chinese transport companies and port operators (Cosco Pacific, China Merchants, China Road and Bridge, etc.). At the same time, the volume of trade between the PRC and the states in 2014-2016 exceeded USD 3 trillion (Чжоу, 2019, с. 38).

In May 2015, the Russian President Vladimir Putin and Xi Jinping entered into an agreement on pairing the SREB and the Eurasian Economic Union (EAEU). The text of the document indicates that the Shanghai Cooperation Organization (SCO) will be the main platform for discussing conjugation issues (Официальный сайт Президента РФ, 2015).

It should be noted that China has concluded agreements on the integration of SREB with infrastructure projects of other states. For example, it was possible to find mutual understanding with the Mongolian project "Steppe Way" (improvement of the China-Russia railway) and the South Korean 
"Eurasian Initiative" (combining the railway routes of North and South Korea with access to the Trans-Siberian Railway) and the Kazakhstani program "Bright Way" (TACC, 2017).

China is transforming the world's political and economic space, it claims to be a global leader, therefore, post-Soviet states, including Russia, and Asian countries, in particular, Korea, Japan, India, Iran and Turkey, are part of its "force field". China seeks to strengthen the expansion of its goods, services and capital to the European developed markets and markets of states that are in the EU and the USA zone of influence.

The project "One belt, one road" will not only give new orders to the "global factory", but will also unite the markets of countries with a population of more than 4 billion people. Its total cost is about USD 8 trillion. Management of such large-scale processes requires the sustainability of the Chinese economy itself and the country's ability to quickly concentrate efforts anywhere and in the direction.

The implementation of the project involves a large-scale and orderly movement of production factors: capital, people, natural resources and information. This is a very difficult task, since there are many conflicts and contradictions between individual countries along the transit route, as well as military-political and economic associations of states. It will be difficult to connect Russia with Poland and Turkey, India with Pakistan and Iran, Azerbaijan with Armenia, Kazakhstan with Turkmenistan, and to introduce common standards for states that are significantly differ from each other in history, culture, socio-economic situation and political system.

Modern global hegemony is based on finances that China has, but no country has yet been able to use them without involving China in its projects. China develops the new "One Belt, One Way" project, following the "principle of joint consultation and use" (Лосев, 2016).

The foreign policy strategy of the formation and promotion on the world stage of the project "One belt, One Way" is designed to solve many domestic problems of China's development. For the state, involvement in world politics in order to ensure the subsequent build-up of national power has become a priority, the achievement of which needs to be strengthened by such domestic "mechanisms" as social cohesion and mobilization ability (see: Marszałek-Kawa et al., 2018). 
Nowadays the countries of the post-Soviet space are in priority of China's intention to develop trade and economic cooperation. The PRC is actively working to promote its own interests in Kazakhstan, Uzbekistan, Tajikistan, Belarus, Moldova and other states, providing loans to these countries and directing a powerful flow of investment into their economies. Such support is necessary for the developing states in the region, which are not always able to implement long-term and large-scale projects. Chinese assistance allows them to attract other foreign partners and to overcome territorial isolation (Anderson, 2008, p. 12).

The Chinese interest in this region is explained not only by Beijing's desire to expand sales markets for its products, but also by its global economic ambitions expressed in the "One Belt, One Way" project, in which substantial attention is paid to the former Soviet republics.

Kazakhstan in this region is the most integrated and stable Chinese partner in the project. Cooperation with Kazakhstan is developing in the primary sector of the economy. In 2006 the first joint project of the two states bypassing Russia was carried out. It was the Kazakhstan gas pipeline Atasu - Alashankou (Жильцов, 2015, с. 98).

In 2016, 688 Chinese companies operated in Kazakhstan. During 2013-2016 their number increased by $35 \%$. In this case, the main role is played by raw materials and industrial projects; there are separate initiatives in the field of agricultural development. In particular, China bought the oil companies "Maten Petroleum" and "KoZhan". Since 2013, low oil prices have been observed, which negatively affects the growth of the Kazakh economy; therefore, the country's current interest in the development of trade and the formation of the corresponding infrastructure is obvious. Kazakhstan is promoting its image as a transport hub that historically connects East and West (Zhiltsov, 2014, p. 38). This approach fits neatly into the concept of "One Belt, One Way" developed by China.

It is planned that three of the six land routes of the Chinese global project will pass through Kazakhstan. The northern route will pass in the north of the state, cross Russia and exit through the Baltic ports or Belarus to Europe. The central route will cross the Caspian Sea through the port of Aktau and Baku, then leave via Azerbaijan and Georgia to Turkey. The southern route will pass through Turkmenistan and Iran. Kazakhstan promptly responded 
to the Chinese "One Belt, One Way" initiative and even prepared its infrastructure development plan, "Nurly Zhol", which aims to become part of the One Belt, One Way initiative, partially funded by Beijing, which is already being implemented in practice. Kazakhstan announced that a new city will be built on the "One Belt, One Way" route in the country by 2025, designed to accommodate 155,000 residents. Creating the necessary infrastructure will require EUR 260 million (Чжоу, 2019, c. 40).

Kazakhstan does not plan to isolate itself from Russia; however, it is actively working to overcome its dependence on it and is trying to diversify transit corridors for export products to the world markets. Infrastructure for the SREB is already under construction in the country: more than $1300 \mathrm{~km}$ of roads have been built, the construction of the Zhetygen-Khorgos railway has been completed, the Altynkol-Khorgos railway crossing on the border with China with a capacity of up to 20 million tons of cargo has been commissioned. The Kazakh authorities are working on a program to expedite the passage of goods through customs posts and remove administrative barriers.

The non-freezing International Sea Trade Port of Aktau is very important in the context of the SREB implementation and its integration with the EEU, through which some export-import operations of the Ural and Siberian regions are carried out. In addition, there is "TRACECA", a transport corridor that forms freight flows, on the one hand, in Western and Central Europe, and on the other hand, in Central and Southeast Asia. "TRACECA" is the only way connecting the countries of Europe and the Asia-Pacific region, which does not pass through the territory of Russia. With the creation of the EEU, the problem of "bypassing" Russia from the south was partially resolved, since freight traffic now follows the customs territory common to Russia, but the question arises of the "East Ray", which is the international transport corridor, called the "Great Bridge" in Kazakhstan.

As part of this project, railway lines were laid in the Zhezkazgan-Saksaulskaya and Shalkar-Beineu sections, which significantly reduced the distance from the Dostyk station to the port of Aktau. Through the Dostyk-Aktogay-Atasu-Zhezkazgan-Saksaulskaya-Aktobe-Saratov branch, access to the infrastructure of the North-South International Transport Corridor appeared, it can highly likely become the Great Bridge on the way from China to Europe. 
The state development program of Kazakhstan "Nurly Zhol", which was officially introduced in November 2014 by the President of Kazakhstan N.A. Nazarbayev, currently sets the direction and pace of state development. The six years during which this state program has been implemented have demonstrated its success and a large role in the economic development of the state. The close pairing of "Nurly Zhol" and the Chinese SREB allows taking into account the existing uncertainty factors, possible challenges and threats. The first and main factor of uncertainty is the absence of a clear goal setting of the SREB from China. It leads to many questions from experts (Bae, 2018, p. 490).

In particular, it is not clear whether the SREB is a geopolitical concept of the " 5 th generation" leaders or a project of economic integration for money and under the auspices of China. Taking into account the recent accents in the speeches of the PRC leaders, and the new assessments of Chinese experts, the SREB is a geopolitical concept (i.e., its economic component takes place). The goal of this project is to strengthen regional economic cooperation in Eurasia, the formation of a "new model of cooperation at the international level and global management". Thus, the main problem arose for Kazakhstan, as well as other countries in the region, consisting in the need to choose priorities in foreign policy. Will the implementation of this project determine the dominance of China in the region from a position of politics and economy? Who exactly from the Chinese side will implement this large-scale project? Will it be a government department or non-governmental organizations (for example, the Silk Road Fund), who will be assigned contacts with foreign partners? (Cheng, 2016, p. 311).

At the same time, the main issue regarding the combination of this concept with the EEU project remains unclear. A key factor of uncertainty is the pursuit of different goals by projects. The goal of the SREB is to promote Chinese products to the markets of the Central Asian countries and the Russian Federation, through them to European and Middle Eastern countries, and then to create a free trade zone in Central Asia, which at the present stage of the EEU's development contradicts its main goal. In this regard, an extremely urgent task is to accelerate the search for real directions and interface points of the EEU and the SREB, and develop mechanisms for their interface. Despite the presence of signed documents, there is still no real 
movement. However, in the absence of appropriate steps in the short term, Central Asian countries will have to choose between China and Russia, and there will be a serious aggravation of the Russian-Chinese relations.

Under such conditions, it is impossible to predict the effectiveness of the SREB implementation in Central Asia. Blocking of the practical implementation of the project by Russia is expected. The second factor of uncertainty is the complexity of Central Asia as a region, interests are intertwined, there are contradictions between Russia, Europe, the USA, India, China, Turkey and Iran, and relations between the states of the region themselves are not simple. In this regard, China, as the initiator of a new project, should direct efforts to modernize these relations, as well as contradictions. Time will tell whether the possibility of practical implementation of the planned project will appear. It should be noted that neither Russia nor the United States have yet succeeded in achieving this goal (Lai, 2017, p. 302).

Another factor of uncertainty is the need to answer the question regarding the decoding of the principle of "common benefit" declared by China in the framework of trade and economic relations, pierced by intense competition. The basis of the SREB project does not consist of concern for the development of the state industrial potential of the countries that it will cross, but consists in the intensive development of the western Chinese regions and their transformation into the Greater Central Asia foreign economic, transport and logistics hub. In other words, there will be an increase in the role of the XUAR, which nowadays is successfully coping with the role of the "industrial workshop" of the Central Asian countries, taking away from the latter the chances of developing the manufacturing sector as part of China's foreign economic contacts with Central Asian states. Moreover, the situation in the countries of the region is expected to deteriorate (from the standpoint of their reindustrialization). At the same time, the main element of uncertainty is the unwillingness of the region's countries to develop the real sector of the economy along with China. Beijing is not sure to invest in regional reindustrialization, because it will receive a competitor for the export of its own manufactured goods (Du, 2018, p. 192).

The main problem is the arrival of the Chinese labor along with the Chinese investments, which is highly undesirable, since there is an excess of own labor in Central Asia. In order to alleviate these concerns, China 
must develop specific breakthrough projects, similar to the situation with the Central Asia-China gas pipeline network, which it will not just implement, taking into account the priority Chinese stake on raw material cooperation, soft loans and the supply of consumption.

The next uncertainty factor is the potential spread of Chinese culture and values as a result of the use of "soft power" as part of the "One Belt, One Way" initiative. Nowadays, the participants of the initiative do not consider this issue; however, it will be sooner or later raised.

China has never considered the countries of Central Asia, including Kazakhstan, as a potential part of its own economy. It perceives the countries of the region as a market for its own goods, a source of natural resources, and transit territory. Chinese investment in Kazakhstan's infrastructure does not imply the development of the real sector. However, it is still unknown whether this situation will change in the framework of the implementation of the SREB project, or not. The companies that China plans to bring to Kazakhstan (environmental safety, the nature of production, prospects for the distribution of goods, etc.) also raise many questions. Will Kazakhstan be able to provide companies with human resources? Will there be a mass labor migration from China? Experts are convinced that an increase in the number of Chinese labor migrants is inevitable, as China's excess industrial capacities will be transferred to Kazakhstan as part of the SREB. In this regard, it is important to take into account the interests of Chinese enterprises and their partners in Kazakhstan (Лихуа, 2019, p. 69).

The prospects for the formation of China's free trade zone in Central Asia also raise many concerns. If in other matters Russia makes concessions, then the EEU free trade zone is of fundamental importance for it. The EEU was established to recreate the industrial potential of its member states, which will be impossible to implement in the absence of restrictions on imports from China. Kazakhstan, which is a member of the EEU and is interested in reindustrialization, should consider this circumstance. China is currently experiencing an economic downturn, which could lead to a reduction in financing opportunities for SREB. Kazakhstan relies on these investments; therefore, it carries certain risks. In Kazakhstan, there is also a complication of the socio-economic situation and a decrease in the consumer potential of 
the population, which may also negatively affect the implementation of the SREB (Wong, 2007, p. 120).

Despite the existence of an agreement on the conjugation of the EEU and the SREB projects, in practical terms nothing has been done. The fact of pairing in Kazakhstan only along the "Nurly Zhol" - EPSB line, as well as the higher competitiveness of the EPSB relative to the EEU, is also alarming. The practical implementation of the SREB will lead to the formation of a new architecture of the geo-economic and geopolitical space of Eurasia, where Central Asia can become the main connecting link. At the same time, there is no doubt that Kazakhstan will play an important role as the largest Central Asian state and the largest economy in the region. The state can really become a "window" for deliveries of Chinese products and goods both to the markets of the EEU countries, and to the markets of neighboring countries and regions (countries of Central Asia, the Caucasus, Turkey, Iran, etc.). Moreover, the unique geopolitical position of Kazakhstan allows it to become a "bridge" between the European Union and China. Today, China ranks third in Kazakhstan's trade turnover (USD 10.6 billion, 14\% of the total trade turnover) and second place in the consumption of Kazakhstani products (12\%). Beijing is also the largest investor in the economy of Kazakhstan. In other words, bilateral relations between states are sustainable. It is also symbolic that the SREB project is correlated with the Kazakhstan New Economic Policy and the "Nurly Zhol" ("Bright Way") initiative, presented to the public in the Message of the President N.A. Nazarbayev in 2014. Both initiatives are aimed at developing infrastructure and industrializing Kazakhstan, and joint implementation, according to Kazakhstani experts, can provide a synergistic effect for the economic development of the state. Such prospects are of particular importance in the context of Kazakhstani economy's modernization, which is necessary in the face of a decline in world oil prices, which is a leading factor in the country's economic development (Гельбрас, 2018, p. 120).

The implementation of the SREB project and its integration with the EEU in the long term provide Kazakhstan with the following advantages:

- Access to the seaports of the member states of the SREB;

- Acceleration and reduction of costs for the delivery of Kazakhstani goods to world markets; 
- Increase in foreign and mutual trade with the countries participating in the pairing;

- Modernization of the economy and infrastructure of Kazakhstan (Гаспарян, 2019, p. 1287).

The Chinese initiative will help the region to leave the transport isolation trap. Today the problem is that the resources extracted in the countries of Central Asia are delivered to consumers at serious costs and require significant efforts for transportation through the territory of transit states. Currently, the so-called "transport curse" is forcing countries that gained political independence to use networks inherited from the Soviet Union, even when their political course involves "curtailing" ties with Russia.

One of the problems of the Kazakh-Chinese relations today is that, despite the dynamic development of economic contacts between the two states, the volume of bilateral trade has halved in recent years. Most likely, this is due to socio-economic problems both in Kazakhstan and in China, a decrease in the purchasing power of Kazakhstanis and a decrease in the volume of goods exported from Kazakhstan to the PRC. However, China remains Kazakhstan's largest trading partner, ranking first in imports from Kazakhstan and second in exports to Kazakhstan. This leads to the problem of dominance of Chinese goods in the markets of Kazakhstan (Гаспарян, 2019, p. 1289).

In the short and medium term, something can hardly be changed in these matters. Except the raw materials industries, Kazakhstan is uncompetitive in comparison with China. Consequently, the Chinese commodity boom is inevitable, and therefore, it can be said that the Chinese commodity expansion in Kazakhstan actually takes place.

Nowadays, it is not clear how Kazakhstan is ready to implement this program in terms of personnel and technological support. Kazakhstan does not have the necessary professional workforce for such production, knowledge and technology are not developed at a high enough level. As part of the integration of the SREB and "Nurly Zhol", cooperation is foreseen in the field of high-tech industries and high-tech economic sectors. Kazakhstan and China are discussing the choice of one or two areas, in which the states will cooperate both at the level of scientific institutes, universities, and in the field of creating joint ventures. However, today specific projects have not yet 
been agreed, at least in the public space there is no information about this (Акматалиева, 2018, p. 143).

Thus, the participation of Kazakhstan in the Chinese initiative "One Belt, One Road" is a very promising and profitable direction of economic development. In fact, the country has great prospects for the development of a transport system for the supply of goods from Asia to Europe. However, nowadays there are many problems associated with the implementation of this project. The main difficult problems are the following:

- The lack of highly qualified personnel;

- The undesirability for Kazakhstan of the influx of Chinese migrants and the expansion of the Chinese culture in the country through the "soft power";

- The obstacles to Kazakhstan's re-industrialization;

- The contradictions between the objectives of the SREB and the EEU;

- The need to maneuver between China and Russia, etc.

In this regard, the participation of Kazakhstan in the implementation of the Chinese initiative "One Belt, One Road" needs a detailed understanding and building of a competent foreign policy regarding China in such a way that takes into account the national interests of Kazakhstan. This process will drag on for many years, because there are no specific approved projects in many areas of the "Nurly Zhol" - SREB interface.

\section{SALTANAT KUZEMBAYEVA, MA}

Faculty of Political Science and International Studies

University of Warsaw

Krakowskie Przedmieście 3, 00-047 Warsaw

s.kuzembayeva@gmail.com

\section{References}

Anderson, C.M., Park, Y.A., Chang, Y.T., Yang, C.H., Lee, T.W., Luo, M. (2008). A game-theoretic analysis of competition among container port hubs: the case of Busan and Shanghai. Maritime Policy \& Management, 35(1), 5-26.

Bae, M.J., Chew, E.P., Lee, L.H. and Zhang, A. (2018). Container transshipment and port competition. Maritime Policy \& Management, 40(5), 479-494. 
Cheng, L.K. (2016). Three questions on China's "Belt and Road Initiative". China Economic Review, 40, 309-313.

Du, J., Zhang, Y. (2018). Does One Belt One Road initiative promote Chinese overseas direct investment?, China Economic Review, 47, 189-205.

Lai, L., Guo, K. (2017). The performance of one belt and one road exchange rate: Based on improved singular spectrum analysis. Physica A, 483, 299-308.

Luttwak, E. (2012). Rise of China vs. the Logic of Strategy. Cambridge: Harvard University Press.

Marszałek-Kawa, J., Dmochowski, T. (red.). (2018). Rozważania o kierunkach współczesnej polityki Chin. Toruń: Wydawnictwo Adam Marszałek.

Marszałek-Kawa, J., Plecka, D., Hołub, A. (red.). (2018). Social Security. Selected Aspects. Toruń: Wydawnictwo Adam Marszałek.

Wong, J. (2014). Reviving the ancient Silk Road: China's new economic diplomacy. Retrieved from: http://www.straitstimes.com/opinion/reviving-the-ancient-silk-road -chinas-new-economic-diplomacy.

Wong, E., Chi, K.; Tienjun, W. (2007). One Belt, One Road. China's Strategy for a New Global Financial Order. Monthly Review, 68(8), 116-122.

Zhiltsov, S.S. (2014). The Caspian Region at the Crossroads of Geopolitical Strategies. Central Asia and the Caucasus, 3, 36-42.

Акматалиева, А.М. (2018). Инициатива «Один пояс-один путь» в Центральной Азии, Сравнительная политика, 4, 139-146.

Жильцов, С.С., Зонн, И.С. (2015). Основные направления политики Китая вКаспийскомрегионе,ВестникМосковскогоуниверситетаимени С.Ю.Витте,2, 96-107.

Лосев, А. (2016). С помощью проекта «Пояса и пути» Китай выстраивает вокруг себя новый экономический порядок. Retrieved from: https://www.vedomosti.ru/ economics/blogs/2016/01/18/624396-poyasa-puti-kitai-ekonomicheskii-poryadok.

Гаспарян, К. (2019). Участие Казахстана в инициативе Китая «Один пояс - Один путь». Постсоветские исследования, 5, 1280-1291.

Гельбрас, В.Г. (2018). Геоэкономическая стратегия Китая. Азия и Африка сегодня, $1,112-122$.

Лихуа, Х. (2019). Перспектива стыковки стратегии «Один пояс - Один путь» и ЕАЭС. Управленческое консультирование, 11, 66-70.

Проект «Один пояс, один путь». Досье. ТАСС (2017). Retrieved from: http://tass. $\mathrm{ru} / \mathrm{info} / 4383152$.

Совместное заявление Российской Федерации и Китайской Народной Республики о сотрудничестве по сопряжению строчтельства Евразийского экономического союза и Экономического пояса Шелкового пути. Официальный сайт Президента РФ (2015). Retrieved from: http://kremlin.ru/supplement/4971.

Чжоу, Ли. (2019). Экономическая полоса Шелкового пути - воплощение мира, развития и процветания. Китай, 10, 33-45. 